Jurnal Psikologi Teori dan Terapan

2016, Vol. 6, No. 2, 102-106, ISSN: 2087-1708

\title{
Perbedaan Perilaku Konsumtif Ditinjau dari Tipe Kepribadian Pada Siswa Sekolah Menengah Atas
}

\author{
Sandra Widyaningrum, Ni Wayan Sukmawati Puspitadewi \\ Program Studi Psikologi Universitas Negeri Surabaya
}

\begin{abstract}
Abstrak: Tujuan penelitian ini adalah untuk menguji perbedaan kecenderungan perilaku konsumtif antara tipe kepribadian introvert dan ekstrovert pada siswa. Penelitian ini menggunakan metode penelitian kuantitatif dengan sampel sebanyak 174 siswa yang berada di kelas XI SMA Negeri 2 Surabaya, yang dipilih berdasarkan teknik random sampling. Instrumen penelitian yang digunakan adalah skala kecenderungan perilaku konsumtif dan skala tipe kepribadian. Analisis data yang dalam penelitian ini adalah uji Independent Sample Test (uji-t) dengan tingkat kesalahan 5\%. Hasil analisis data menunjukkan nilai signifikasi variabel kecenderungan perilaku konsumtif dengan tipe kepribadian sebesar 0,049 ( $p<0,05)$, yang berarti terdapat perbedaan kecenderungan perilaku konsumtif ditinjau dari tipe kepribadian introvert dan ekstrovert. Penelitian ini juga menunjukkan adanya perbedaan nilai rata-rata pada variabel kecenderungan perilaku konsumtif siswa yang bertipe kepribadian ekstrovert sebesar 102,63 dan pada siswa yang bertipe kepribadian introvert sebesar 97,91. Hal ini menunjukkan bahwa kecenderungan perilaku konsumtif pada siswa yang memiliki tipe kepribadian ekstrovert lebih tinggi daripada siswa yang memiliki tipe kepribadian introvert.
\end{abstract}

Kata Kunci: Perilaku konsumtif, tipe kepribadian, introvert, ekstrovert, siswa

\begin{abstract}
The purpose of this research is to study the differences of consumptive behavior tendences between introvert and ekstrovert personality types among students. This research used quantitative method, involved 174 subjects from Senior high School students SMA Negeri 2 Surabaya Grade XI who were chosen by random sampling. The instruments used for collecting data were scales of consumptive behavior tendencies and personality types. Data analyzed by Independent Sample Test (t-test) with error level of 5\%. The result of analysis showed a significance value of consumptive behavior tendencies and the personality types is 0.049 ( $p<0.05)$, means there is a difference tendency of the consumptive behavior in terms of introvert and ekstrovert personality types among participants. This study also showed differences in the average (mean) value of the variable consumptive behavior tendencies of students who have extrovert personality at 102.63 and the student who have introvert personality at 97.91. This indicated that the tendencies of consumptive behavior on students who have extrovert personality is higher than the students who have introvert personality.
\end{abstract}

Key words: Consumptive behavior, personality type, introvert, extrovert, students

Korespondensi tentang artikel ini dapat dialamatkan pada Sandra Widyaningrum melalui email:sandrawidya17@gmail.com. 
Perilaku konsumtif adalah tindakan individu yang secara langsung terlibat dalam memperoleh dan menggunakan barang atau jasa dengan mendahulukan proses pengambilan keputusan. Predikat konsumtif biasanya melekat pada diri seseorang apabila seseorang tersebut membeli barang atau jasa di luar kebutuhan rasional (Mangkunegara, 2009). Fenomena yang terjadi saat ini menunjuk-kan bahwa masyarakat yang berperilaku konsumtif tidak melihat usia, jenis kelamin dan pekerjaan. Mereka bisa saja dari kaum remaja, dewasa dan orang tua namun beberapa penelitian melaporkan bahwa remaja cenderung berperilaku konsumtif. Hal ini sejalan dengan pernyataan Wagner (2009) bahwa remaja ingin diakui keberadaannya oleh lingkungan sekitar sehingga perilaku konsumsi yang dilakukan oleh remaja hanya untuk bisa diterima dan menjadi bagian dari lingkungan tersebut. Remaja dapat dikaitkan dengan perilaku konsumtif karena sebagian besar dari remaja belum mempunyai penghasilan sendiri namun banyak remaja yang memiliki pengeluaran cukup besar.

Munandar (2006) karakteristik perilaku konsumtif yaitu, pertama orang yang mudah terbujuk rayuan penjual. Kedua, punya perasaan tidak enak pada penjual. Orang yang ketika masuk toko, dan tidak membeli sesuatu memiliki perasaan yang tidak enak pada penjual, apalagi jika sampai mencoba dan bertanya-tanya tentang barang dan kemudian tidak jadi membeli. Ketiga, orang yang suka terburuburu. Hal tersebut akan membuat seseorang akan tergesa-gesa dalam menentukan pilihan barang yang akan dibelinya. Individu akan membeli barang karena keinginan sesaat dan tidak memiliki banyak pertimbangan.

Schiffman dan Kanuk (2004) menyatakan bahwa dalam membeli barang konsumen dipengaruhi motif emosional seperti hal-hal yang bersifat pribadi atau subyektif seperti status, harga diri, perasaan cinta dan lain sebagainya.
Konsumen yang dipengaruhi oleh motif emosional tidak mempertimbangkan apakah barang yang dibelinya sesuai dengan dirinya, sesuai dengan kebutuhannya, sesuai dengan kemampuannya dan sesuai dengan standar atau kualitas yang diharapkannya. Hal inilah yang menye-babkan individu dapat berperilau konsumtif.

Mangkunegara (2009) menyebutkan bahwa ada dua (2) faktor yang mempengaruhi perilaku konsumtif seseorang, yaitu kekuatan sosial budaya dan kekuatan psikologis. Salah satu kekuatan psikologis yaitu kepribadian karena kepribadian dapat mempengaruhi kecenderungan perilaku seorang individu. Faktor kepribadian merupakan faktor bawaan yang melekat yang dipengaruhi oleh faktor genetik dan lingkungan.

Eysenck (dalam Alwisol, 2009) juga mengklasifikasikan seseorang berdasarkan dua tipe kepribadian, yaitu tipe kepribadian introvert dan tipe kepribadian ekstrovert. Orang introvert lebih menyukai aktivitas yang tidak menarik dan cenderung membosankan, mereka lebih menyukai aktivitas rutin mereka dengan orang-orang yang sama. Orang yang introvert lebih menarik diri dan menghindari riuh-rendah situasi di sekelilingnya yang dapat membuatnya kelebihan rangsangan. Pribadi introvert memiliki sembilan trait, yaitu: tidak sosial, pendiam, pasif, ragu, banyak fikiran, sedih, penurut, pesimis, penakut. Pribadi ekstrovert memilih berpartisipasi dalam kegiatan bersama, pesta hura-hura, olahraga beregu (sepak bola, arung jeram), minum alkohol dan menghisap mariyuana. Eysenck berpendapat bahwa pribadi ekstrovert, kebalikan dari pribadi introvert dan menyebutkan sembilan trait kepribadian ekstrovert, yaitu sosiabel, lincah, aktif, asertif, mencari sensasi, riang, dominan, bersemangat, dan berani. Karakter introvert cenderung menyendiri, sedangkan ekstrovert cenderung suka berkelompok.

Hal ini sejalan dengan penelitian yang dilakukan Chen (2011) mengungkapkan 
bahwa faktor kepribadian memiliki kaitan dengan niat konsumen untuk berpartisipasi dalam pembelian online. Lu \& Kuo (2010) menunjukkan bahwa pada ekstrovert nilai sosial (29.7\%) lebih tinggi dibandingkan pada introvert (26.4), pada introvert nilai emosional (39.1\%) lebih tinggi dari pada ekstrovert (35.9\%), dan pada introvert nilai uang/harga $(32 \%)$ lebih tinggi dari pada ekstrovert (29.5\%), sehingga dapat disimpulkan bahwa ekstrovert lebih cenderung pada nilai sosial, sedangkan pada introvert lebih cenderung pada nilai emosional dan harga.

Shohibullana (2014) menyatakan bahwa siswa yang bersekolah berdekatan dengan mall memiliki tingkat perilaku konsumtif yang lebih tinggi dibanding siswa yang bersekolah jauh dengan mall. Salah satu sekolah di kawasan pusat kota Surabaya yang berlokasi dekat dengan mall adalah Sekolah Menengah Atas (SMA) Negeri 2 Surabaya. Pengumpulan data awal dilakukan penulis pertama dengan melakukan wawancara pada guru sekolah dan data dokumen. Hasil data menunjukkan bahwa sebagian besar siswa SMA Negeri 2 Surabaya berasal dari keluarga dengan tingkat ekonomi menengah ke atas. Hanya minoritas kecil yang berasal dari keluarga menengah ke bawah. Siswa yang berlatar belakang keluarga dengan tingkat ekonomi menengah ke atas cenderung memiliki daya beli yang tinggi terhadap barang yang digunakan, seperti tas, telepon genggam, jam tangan dan lain-lain. Lokasi SMA Negeri 2 Surabaya dekat dengan beberapa pusat perbelanjaan atau mall seperti Grand City, Surabaya Plaza, Tunjungan Plaza, dan Kapasan Plaza. Akses yang dekat dengan mall-mall besar di Surabaya memungkinkan siswa mengunjungi mall tersebut untuk berbelanja.

Berdasarkan latar belakang di atas, penelitian ini bertujuan untuk menguji apakah ada perbedaan kecenderungan perilaku konsumtif ditinjau dari tipe kepribadian introvert dan ekstrovert pada siswa di SMA Negeri 2 Surabaya.

\section{Metode}

Penelitian ini menggunakan metode penelitian kuantitatif dengan rancangan penelitian komparatif Penelitian ini melibatkan siswa kelas XI di SMA Negeri 2 Surabaya. Berdasarkan populasi yang berjumlah 306 siswa kelas XI yang memiliki karakteristik yang sama maka pengambilan sampel penelitian dilakukan dengan menggunakan teknik random sampling dimana semua anggota populasi mendapatkan kesempatan yang sama untuk menjadi anggota sampel penelitian, sehingga dari 306 siswa didapatkan 174 siswa yang akan digunakan sebagai subjek penelitian.

Instrumen yang digunakan adalah skala kecenderungan perilaku konsumtif dan skala tipe kepribadian yang menggunakan model skala likert. Teknik analisis data yang digunakan adalah analisis Independent Sample Test yang bertujuan untuk membandingkan dua rata-rata yakni kecenderungan perilaku konsumtif siswa yang mempunyai tipe kepribadian introvert dan ekstrovert. Analisis Independent Sample Test dipilih karena data dari kedua variabel berupa data interval. Analisis tersebut dilakukan setelah uji persyaratan analisis yang meliputi: uji normalitas dan homogenitas.

\section{Hasil dan Pembahasan}

Hasil data statistik deskriptif menunjukkan bahwa nilai rata-rata (mean) kecenderungan perilaku konsumtif pada siswa bertipe kepribadian ekstrovert sebesar 102,63 dengan standar deviasi sebesar 16,517 sedangkan nilai rata-rata (mean) kecenderungan perilaku konsumtif pada siswa bertipe kepribadian introvert sebesar 97,91 dengan standar deviasi sebesar 14,154.

Hasil analisis data yang dilakukan dengan menggunakan Independent Sample Test (uji-t) diketahui bahwa hipotesis penelitian diterima yang berarti ada 
perbedaan kecenderungan perilaku konsumtif ditinjau dari tipe kepribadian introvert dan ekstrovert di SMA Negeri 2 Surabaya. Hal ini dibuktikan dengan nilai signifikansi atau probabilitasnya sebesar $(\mathrm{p})=0,049(\mathrm{p}<0,05)$.

Mangkunegara (2009) menyebutkan bahwa ada dua faktor yang mempengaruhi perilaku konsumtif seseorang, yaitu kekuatan sosial budaya dan kekuatan psikologis. Salah satu kekuatan psikologis yaitu kepribadian karena kepribadian dapat mempengaruhi kecenderungan perilaku seorang individu, dimana menurut beberapa peneliti ada tipe kepribadian tertentu yang mempengaruhi munculnya kecenderungan perilaku konsumtif pada seseorang.

Penelitian ini menunjukkan adanya perbedaan nilai rata-rata (mean) pada variabel kecenderungan perilaku konsumtif pada siswa yang bertipe kepribadian ekstrovert sebesar 102,63 dan pada siswa yang bertipe kepribadian introvert sebesar 97,91. Hal ini menunjukkan bahwa kecenderungan perilaku konsumtif pada siswa yang memiliki tipe kepribadian ekstrovert lebih tinggi daripada siswa yang memiliki tipe kepribadian introvert. Alasannya adalah karakteristik kepribadian ekstrovert lebih aktif dan energik dalam melakukan segala sesuatu, termasuk dalam melakukan pembelian jika dibandingkan dengan tipe kepribadian introvert yang memiliki karakteristik tidak aktif dan kurang energik dalam melakukan sesuatu, sehingga dengan perbedaan tersebut dapat menunjukkan kecenderungan perilaku konsumtif yang berbeda pula.

Swastha (2008) mengungkapkan bahwa calon pembeli yang akan dilayani mempunyai kesamaan secara umum dari segi usia, penghasilan, pendidikan, dan karakteristik terukur lainnya, tetapi akan dijumpai banyak jenis kepribadian yang berbeda antara calon pembeli, sehingga pelayanan yang akan diberikan harus sesuai dengan kepribadian pembeli. Individu dengan tipe kepribadian ekstrovert lebih dipengaruhi oleh dunia objektif, dimana orientasinya tertuju ke luar, pikiran, perasaan, serta tindakannya terutama ditentukan oleh lingkungannya baik dari lingkungan sosial maupun lingkungan non sosial, mempunyai sikap positif terhadap masyarakat: lebih terbuka dan mudah bergaul. Individu ekstrovert mempunyai pilihan seni yang tertuju pada gambar-gambar yang berwarna dan model baru (Suryabrata, 2010).

Siswa yang bertipe kepribadian ekstrovert memiliki kecenderungan dalam berperilaku konsumtif karena berdasarkan karakteristiknya mereka tergolong orang yang berani mengambil resiko, termasuk dalam pembelian produk jika dibandingkan dengan siswa yang memiliki tipe kepribadian introvert. Hal ini didukung pendapat Setiadi (2003) mengungkapkan bahwa tipe kepribadian ekstrovert cenderung memiliki perilaku konsumtif yang inovatif yaitu derajat seseorang untuk menginginkan atau mencoba sesuatu yang baru termasuk dalam penggunaan produk baru atau merek terbaru.

Individu dengan tipe kepribadian introvert cenderung mengarahkan dan menyalurkan perhatiannya ke dalam diri sendiri dimana nilai-nilai subjektif lebih berpengaruh pada dirinya daripada nilainilai objektif (Naisaban, 2003). Individu introvert dalam membeli produk lebih memperhatikan kegunaan produk tersebut daripada terpengaruh terhadap trend atau pola konsumsi golongan sosial ekonomi atas karena mereka berusaha membeli barang untuk tidak menjaga kedudukan, harga diri dan kebutuhan akan diakui oleh orang lain disekitarnya (Sumartono, 2002).

Individu yang memiliki tipe kepribadian ekstrovert memiliki perilaku konsumtif yang lebih tinggi daripada individu dengan tipe kepribadian introvert. Penelitian yang mendukung adalah penelitian Rubianti (2014) yang mengungkapkan bahwa terdapat perbedaan minat membeli di media online ditinjau dari tipe kepribadian introvert dan ekstrovert. Tipe kepribadian ekstrovert lebih berminat dalam membeli 
di media online $(30,27 \%)$ dibandingkan dengan tipe kepribadian introvert $(28,04 \%)$. Kecenderungan perilaku konsumtif tidak hanya dilatar belakangi oleh faktor kepribadian, faktor-faktor lain dapat berasal dari budaya, kelas sosial, kelompok anutan, keluarga, sikap dan keyakinan, sehingga untuk penelitian selanjutnya diharapkan dapat menggunakan variabel yang lebih beragam agar dapat menggunakan variabel penelitian yang lebih lengkap dan menambah ragam pengetahuan di bidang psikologi.

\section{Simpulan}

Berdasarkan hasil penelitian, maka dapat ditarik kesimpulan bahwa ada perbedaan kecenderungan perilaku konsumtif ditinjau dari tipe kepribadian introvert dan ekstrovert pada siswa sekolah menengah atas yang menjadi populasi penelitian ini. Siswa yang memiliki tipe kepribadian ekstrovert memiliki perilaku konsumtif yang lebih tinggi daripada individu dengan tipe kepribadian introvert.

\section{Daftar Pustaka}

Alwisol. (2009). Psikologi Kepribadian. Malang: UMM Press.

Chen, T. (2011). Personality Traits Hierarchy of Online Shoppers. Journal of Marketing Studies, 3 (4), Online. http://www.ccsenet.org/. Diakses 5 Desember 2015.

Lu, H. P \& Kuo, L. H. (2010). The Influence of Extro/Introversion on the Intention to Pay for Social Networking Sites. Journal of Information \& Management, 47 (3), Online. http://www.researchgate.net. Diakses 5 Desember 2014.

Mangkunegara, A. P. (2009). Perilaku Konsumen. Bandung: PT Refika Aditama.

Munandar, A.S. (2006). Psikologi Industri dan Organisasi. Jakarta: Universitas Indonesia.

Naisaban, L. (2003). Psikologi Jung. Jakarta: Grasindo.

Rubianti, L. (2014). Minat Membeli di Media Online Ditinjau dari Tipe Kepribadian. Jurnal Psikologi, 2 (1), Online. http://ejournal.umm.ac.id/. Diakses 4 Desember 2015.
Schiffman, L. G. \& Kanuk, L. L. (2004). Perilaku Konsumen. (Alih Bahasa: Zulkifli Kasif). Jakarta: Indeks.

Setiadi, J. (2003). Perilaku Kosnumen, Konsep dan Implikas untuk Strategi dan Penelitian Pemasaran. Bogor: Kencana.

Shohibullana, I. H. (2014). Kontrol Diri dan Perilaku Konsumtif pada Siswa SMA (Ditinjau dari Lokasi Sekolah). Jurnal Psikologia. 2 (1), Online. http://ejournal.umm.ac.id/. Diakses 3 Desember 2013.

Sumartono. (2002). Terperangkap dalam Iklan: Meneropong Imbas Pesan Iklan Televisi. Bandung: Alfabeta.

Suryabrata, S. (2010). Psikologi Kepribadian. Jakarta: Rajawali.

Swastha, B. (2008). Manajemen Pemasaran Modern. Liberty: Yogyakarta.

Wagner. (2009). Gaya Hidup Shopping Mall sebagai Bentuk Perilaku Konsumtif pada Remaja di Perkotaan. Skripsi. Online. http://repository.ipb.ac.id/. Diakses 3 Desember 2015. 